\title{
Analysis on How the Joint Venture Party Organization Exerts Its Political Core Role
}

\author{
Li Chao ${ }^{1, a}$, Xue Muzi ${ }^{2, b^{*}}$ \\ ${ }^{1}$ Beijing Benz Automobile Co., Ltd., Daxing, Beijing, China \\ ${ }^{2}$ Beijing Benz Automobile Co., Ltd., Daxing, Beijing, China \\ alic@bbac.com.cn \\ b*Xuemz@bbac.com.cn
}

\begin{abstract}
As an important form of Chinese economic organization, Sino-foreign joint ventures are different from state-owned enterprises in terms of management system, business philosophy, ideology, cultural background, etc., which make them have a relatively special aspect when carrying out party building work, and they can be used effectively. The political core role of party organizations in joint ventures is a subject that requires in-depth study. This article compares the similarities and differences between joint ventures and state-owned enterprises' party building work, and combines the actual work to discuss in depth how to exert the political role of joint venture party organizations.
\end{abstract}

Keywords: Joint venture, party organization, political core role, focus point

\section{浅谈合资企业党组织如何着力发挥政治核心作用}

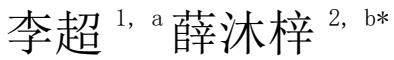

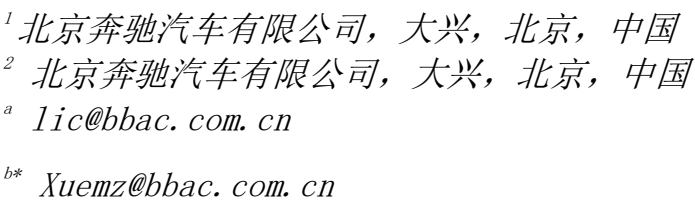

摘要

中外合资企业作为我国经济组织的重要形式，因其在管理体制、经营理念、思想意识、文化背景等方面与国有 企业存在着差异，使得在开展党建工作时具有相对特殊的一面，有效发挥合资企业党组织的政治核心作用是需 要深入研究的一项课题。本文通过比较合资企业与国有企业党建工作的异同点，结合工作实际，深入探讨了如 何着力发挥合资企业党组织的政治作用。

关键词：合资企业，党组织，政治核心作用，着力点

\section{1. 前言}

中国共产党是中国特色社会主义事业的领导核 心, 坚持党的领导, 加强党的建设, 是党和国家的根 本所在、命脉所在, 是全国各族人民的利益所系、幸 福所系。中外合资企业作为我国经济组织的重要形式, 也必须充分发挥党组织在企业中的政治核心作用。但 合资企业在管理体制、经营理念、思想意识、文化背
景等方面与国有企业存在着差异，使得合资企业开展 党建工作具有其相对特殊的一面, 要发挥党组织的核 心作用，需要从合资企业的特点出发，找准着力点， 探索新路子，切实以党的建设促进合资企业各项工作 的全面发展，真正做到让党旗在合资企业高高飘扬。 


\section{2. 合资企业党建工作的主要特点}

合资企业是指由中国投资者和外国投资者共同 出资、共同经营、共负盈亏、共担风险的企业。合资 企业党建工作的主要特点, 可以通过合资企业与国有 企业党建工作的比较中体现出来。

\section{1. 合资企业与国有企业党建工作的同一性}

\section{1. 1. 有共同的中心任务}

不管是合资企业，还是国有企业，其共同的中心 任务都是要争取投资者最大投资收益。这就决定了合 资企业党组织必须紧紧围绕这一中心任务来展开党 的工作, 离开这一中心, 党组织就失去了在企业生存 发展的基础。

\section{1. 2. 有共同的根本宗旨}

无论是合资企业, 还是国有企业, 党建工作的主 要对象是职工。关心群众、帮助群众、凝聚群众是企 业党组织坚持全心全意为人民服务的根本宗旨的体 现。合资企业和国有企业党组织都要把坚持全心全意 依靠职工办企业, 切实关心职工利益, 为职工排忧解 难作为工作的重要内容。

\section{1. 3. 有共同的政治责任}

合资企业虽然有外商投资, 但也要适合中国国情, 在中方职工占绝对优势的情况下, 党组织也要承担重 要的政治使命, 那就是企业不仅要创造良好的经济效 益, 而且要注重社会效益, 即在生产物质产品的同时 还要生产精神产品, 这与国有企业是一致的。

\section{1. 4. 有共同的衡量标准}

衡量企业生产业绩的根本标准是生产力标准。同 样, 在党建工作衡量标准上也要以生产力标准作为 “参数”, 企业的经济效益也是检验党建成效的最重 要的方面。当然, 不能把党建工作和经济工作简单地 划等号, 党建工作还有具体标准, 但根本标准只有一 条, 就是生产力标准, 这方面合资企业与国有企业是 相通的。

\section{2. 合资企业与国有企业党建工作的差异性}

\section{2. 1. 管理体制上有差异}

合资企业在管理体制上较国有企业行政独立性 较强, 党组织在企业中虽然公开身份、公开活动, 但 不能像国有企业那样以直接名义参与企业各项管理 工作。

\section{2. 2. 工作环境上有差异}

在共事对象上, 合资企业一般有很多外来工作人 员，他们来自不同国家、不同的社会制度、不同的文 化背景、不同的生活习俗，在自身利益取向上与中方 存在着明显的差别。这些特殊情况决定了合资企业党 组织在开展工作时不能像国有企业那样容易放开, 而 要考虑内外有别, 讲究策略和方式方法。在职工心态 上，合资企业员工 “雇佣” 思想较重，有人认为自己 是在给外国老板打工, 缺少安全感和稳定感, 劳动热 情大都靠收入多少调节。而国有企业员工普遍对企业 党组织存在着一种依附感、信任感、安全感。

\section{2. 3. 干部管理上有差异}

国有企业党组织对干部的任用、教育、管理、监 督、控制较直接和严格。而合资企业受干部管理体制、 管理权限限制, 党组织对干部的管理较国有企业限制 较多。

\section{2. 4. 活动方法上有差异}

合资企业工作节奏普遍较快, 党组织活动就要依 据这一特点讲究方式方法, 不能完全套用国有企业的 做法, 在开展工作一定要注意做到原则性与灵活性的 结合, 党的活动与群众活动的结合, 相对集中与分散 活动的结合, 脱产与业余的结合。

\section{3. 合资企业党组织发挥政治核心作用的着力 点}

\section{1. 提开党组织决策影响力}

\section{1. 1. 贯彻执行党和国家方针政策}

要抓好思想理论建设这个根本, 组织学习宣传党 和国家方针政策，学习中国特色社会主义理论体系。 同时, 要坚决执行党和国家方针政策, 推动企业积极 承担经济责任、政治责任和社会责任。在当前阶段, 要深入开展党史学习教育, 要坚持以马克思列宁主义、 毛泽东思想、邓小平理论、“三个代表” 重要思想、科 学发展观、习近平新时代中国特色社会主义思想为指 导, 深入学习贯彻党的十九大和十九届二中、三中、 四中、五中全会精神, 紧紧围绕学懂弄通做实党的创 新理论, 坚持学习党史与学习新中国史、改革开放史、 社会主义发展史相贯通, 做到学史明理、学史增信、 学史崇德、学史力行, 引导广大党员、干部增强 “四 个意识”、坚定 “四个自信”、做到 “两个维护”, 不断 提高政治判断力、政治领悟力、政治执行力, 守正创 新抓住机遇, 锐意进取开辟新局。各级党组织要不折 不扣落实管党治党责任清单, 压实主体责任。

\section{1. 2. 将党组织打造成中方核心管理平台}

合资企业中，要发挥党委政治核心作用，最关键 
的就是要将企业一级的党组织打造成中方的核心管 理平台。打造核心管理平台的重要措施之一，就是构 建党委会、党委扩大会、基层支部书记例会相结合的 党组织会议体系, 并以此确保党组织参与企业重大决 策。党委会讨论公司党建和生产经营重大工作, 如“三 重一大” 决策等, 一定要先通过党委会讨论, 在中方 领导班子形成统一意见后再提交公司董事会和经管 会决策; 党委扩大会统一全体中方干部思想意志, 部 署推进上级党委的战略决策和重点工作, 发挥党委统 揽全局作用; 基层支部书记例会实现党委工作的落地 和精神的上传下达, 确保党的工作全覆盖。同时, 实 行党委委员责任分区, 强化党对经济工作的领导, 特 别是对只有外方领导班子直管的部门, 将其纳入到相 关党委委员的管理责任中, 实现党委对业务管理的全 覆盖。

\section{1. 3. 以党建品牌建设引领助推企业发展}

把打造党建品牌作为引领助推企业发展的有效 抓手。党建品牌是具有示范作用、导向作用和辐射带 动作用的党建工作理念、标识或载体。在创建党建品 牌的过程中, 必须把党建品牌的创建与服务企业、服 务基层、服务群众紧密结合起来, 使党的建设与推动 企业科学发展相一致。同时要推动企业党建品牌在基 层的落地实施, 结合基层实际因地制宜层层拓展, 把 企业经营的理念贯穿于党建品牌创建始终, 实现党建 品牌与企业发展的有机结合, 并最终以党建品牌建设 引领助推企业发展。

\section{2. 坚持服务生产经营不偏离}

\section{2. 1. 把促进企业发展作为党组织的核心目标}

合资企业党组织的工作目标要始终做到 “围绕经 营抓党建, 抓好党建促发展”。党组织要按照中央规 定, 按时召开党员代表大会或全体党员大会, 在大会 上制定中长期党建工作规划和企业经营工作规划, 确 保党建与经营中长期目标一致。每年, 党组织要结合 发展形势, 制定与企业自身发展相一致的工作目标, 真正做到目标同向、任务同担、责任同当。在具体实 施的过程中, 要将企业的全年工作目标和任务, 作为 党组织目标管理的重要内容, 分解细化为各项子目标, 落实到党建工作部门和基层党组织, 做到与企业经济 工作目标同步发布、同步实施、同步考核。

\section{2. 2. 确保基层落实党组织促进生产经营的责任}

坚持服务生产经营不偏离, 最终落实还要靠基层。 为了确保基层落实企业党组织在服务生产经营中责 任, 可以与基层党组织签订责任书。责任书的内容不 仅要包括党建工作的责任、党风廉政建设的责任, 同 时也应该包括生产经营的责任、安全管理的责任等等。

\section{2. 3. 构建与企业发展相适应的企业文化}

未来竞争在文化，作为企业的基因，文化是企业 持续发展的重要因素, 构建与企业发展相适应的企业 文化体系是服务生产经营的重要内容。中外合资企业 因其不同投资主体所带来的不同文化背景, 产生了不 同意识形态。因此, 合资企业党组织只有把企业文化 建设作为党建工作的切入点和着力点, 将党的思想政 治工作优势、企业精神等, 和外方的管理制度、经营 理念和技术成果及国际经营模式紧密结合起来, 才能 催生出具有自身特色的企业文化。合资企业虽然有外 方投资，但必须始终牢记企业的性质是党领导下的合 资企业。在企业文化建设上, 应当注重发挥党组织的 导向作用, 在不同的时期、不同的阶段, 深入开展不 同专题的形势任务教育, 凝聚人心, 营造职工心顺劲 足的企业氛围。

\section{3. 打造一支素质过硬的干部人才队伍}

\section{3. 1. 坚持党管干部原则}

干部队伍是企业发展的关键少数, 坚持党管干部 原则是我们党干部路线的根本原则。合资企业坚持党 管干部原则重点不在于管不管人头，管多少人头，而 要由过去管具体人头的微观管理方式向管选人用人 标准、用人的程序、育人的渠道等宏观管理转变, 把 党管干部工作重心前移, 重点在规范选人、用人规则 程序中, 实现党管干部原则与公司治理结构及依法用 人相结合。同时, 还要加强对干部的考核与培养, 针 对领导班子、中层干部、基层干部等不同群体, 实施 不同的考核与培养政策, 尤其要通过考核与培养, 提 升干部的业务能力素质, 锤炼过硬的作风。

\section{3. 2. 坚持党管人才原则}

人才是企业发展的第一资源, 是企业发展的第一 支撑力。合资企业党组织坚持党管人才, 要着力优化 人才结构, 深化人才培养, 激发人才活力。优化人才 结构, 重点是要结合企业对人才的需求, 加强人才盘 点, 制定人才招聘规划, 特别是要加强中方人员对外 方人员的替代。深化人才培养, 重点是要完善人才培 训体系, 加强培训管理, 不断提升人才的能力素质。 要激发人才活力, 重点是要完善人员晋升机制, 尤其 是针对具有大量技术员工的企业，应构建双晋升通道， 实现管理序列与技术序列的同步晋升, 激发员工创造 活力。同时, 合资企业还应该用好专家队伍, 发挥专 家团队的智力优势, 努力发挥专家团队在能力建设与 人才培育方面的指导作用。 


\section{4. 建强基层党组织, 发挥党支部战斗堡垒 作用}

\section{4. 1. 加强基层党建创新}

基层党组织是企业党的建设的根基, 要坚持建强 基层党组织不放松, 确保企业发展到哪里、党的建设 就跟进到哪里、党支部的战斗堡垒作用就体现到哪里。 发挥支部战斗堡垒作用的一个重要载体是加强党支 部在创新攻关中的作用, 可以通过党建创新课题、党 代表提案、党员攻关等发挥基层党组织的创造精神, 激发基层党建创新活力。同时, 要强化基层党建考核, 加大对基层党组织的考核和奖励力度, 把基层党建考 核与基层单位的业绩绩效相挂钩, 确保支部战斗堡垒 作用发挥。

\section{4. 2. 加强党员和党支部书记队伍建设}

党员是党的一切活动的主体, 要以增强党性、提 高素质为重点, 加强党员教育管理, 建立健全党员激 励、关怀、帮扶机制。要做好在专业技术人员、生产 经营能手、青年职工中发展党员工作, 努力把生产经 营骨干培养成党员, 把党员培养成经营骨干。要严格 党内组织生活, 按期开展专题组织生活会, 开展民主 评议党员, 及时处置不合格党员。党支部书记是基层 党组织的带头人, 是建强支部的关键力量。要选好配 强党支部书记, 注重从优秀经营管理类人员中选拔。 加大对党支部书记的教育培养和实践锻炼力度, 努力 建设一支善于围绕企业生产经营开展党建工作的高 素质、复合型党支部书记队伍, 同时要注重党支部书 记的发展提升, 注意从优秀党支部书记中选拔管理干 部。

\section{4. 3. 加强对群团工作的领导}

群团事业是党的事业的重要组成部分, 群团组织 可以散发温暖人心的力量, 在加强基层党组织建设过 程中, 要注重加强对群团工作的领导, 发挥群团组织 的作用。合资企业也要全心全意依靠职工群众, 通过 召开职工代表大会、厂务公开等, 让群众参与企业发 展的讨论, 让群众共享企业发展的成果。要发挥工会 组织的维护、服务职能, 依法保证员工合法权益, 关 爱职工生活。要发挥共青团组织在青年工作中的优势, 打造一支企业发展的生力军和强大的后备力量。

\section{4. 结论}

发挥合资企业党组织的政治核心作用至关重要, 党中央关于全面从严治党的战略部署对于加强合资
企业党建工作也提出了更高更新的要求, 必须以高度 的历史责任感和使命感, 积极探索合资企业加强党建 工作的新思路、新途径、新方法, 完善机制、加强管 理、发挥作用，切实加强合资企业党的建设。

本文以在中外合资企业开展党的建设工作为出 发点, 通过合资企业与国有企业党建工作, 总结归纳 合资企业党建工作的主要特点, 主要体现在同一性和 差异性。在此基础上，探索分析合资企业党组织发挥 政治核心作用的着力点, 以综合提升党组织决策影响 力、坚持服务生产经营不偏离、打造一支素质过硬的 干部人才队伍、建强基层党组织以发挥党支部战斗堡 垒作用等四个方面为主要着力点, 探索新路子, 切实 以党的建设促进合资企业各项工作的全面发展, 真正 做到让党旗在合资企业高高飘扬, 对广大合资企业开 展党建促经营工作有一定的指导意义。

\section{REFERENCES}

[1] He Peizeng. (2016) Talking about how to strengthen the party building work of joint ventures under the new situation [J]. China Training. 16: 228-228.

[2] Shu Youyu. (2003) Some thoughts on the party building work of joint ventures[J]. Research and communication[J]. 4: 6-7.

[3] Xu Heyi. (2003) A Preliminary Study on Party Building and Ideological and Political Work in Sinoforeign Joint Ventures [J]. People's Forum. 11: 4647.

[4] Lin Xiaochun. (2012) A Preliminary Study of Party Building and Ideological and Political Work in Sinoforeign Joint Ventures [J]. Ideological and Political Education Research. 6: 80-81.

[5] He Qingdong. (2010) Exploration and practice of party building in Sino-foreign joint ventures [J]. "Journal of Petrochemical Managers College". 1: 14.

[6] The General Office of the Central Committee of the Communist Party of China forwarded the "Opinions of the Organization Department of the Central Committee and the Party Committee of the Stateowned Assets Supervision and Administration Commission of the State Council on the Party Committee of Central Enterprises in Giving Full Play to the Political and Renewal Role of the Modern Enterprise System" (Zhongbanfa [2013] No. 5). 